\title{
Henriët Graafland
}

\section{The "Waiting Game" in the Middle East}

American Cold War perceptions influencing the recognition of the state of Israel

Since the foundation of the state of Israel on May 14, 1948, the United States of America had good reasons to support the new state in the Middle East. At least, this is what people in the West tend to think. However, in the first years of its existence, Israel and the United States of America (US) both took a somewhat neutral stance towards each other. In order to understand why the current close allies did not have a very close relationship at the immediate start of the state of Israel, a historical analysis of the context of the aftermath of the Second World War (1939-1945) is essential. After 1945, the US and the Soviet Union (USSR) soon broke their wartime alliance and divided the world into two spheres of influence. A bipolar world order generally referred to as the Cold War (1946-1989) emerged in Europe and quickly spread across the globe. Still, both superpowers recognized the Israeli state within a day of its establishment. The influence of the Cold War suspicion in the decision to support the state of Israel has not been examined thoroughly yet. This article aims to explain the impact of Cold War perceptions in the decision-making processes of the American government and its outcomes. 


\section{Graafland}

\section{The origins of the Cold War}

Generally speaking, three different schools of thought on the origins of the Cold War can be discerned. During the early Cold War, the Americans adhered most to the orthodox or traditional school. This school perceived the actions and ideology of the Soviet leader, Joseph Stalin, in Eastern Europe as aggressive and expansionist. While the British, the Americans and the Soviets had been allies against the Nazis, they could not agree on what do to with Germany, neither during the war-period conferences of Tehran and Yalta, nor after the war had been won. Stalin made clear that he wanted to have a sphere of influence in Eastern Europe and asked the US to recognize the communist governments of Romania and Bulgaria. The new President of the United States of America, Harry Truman, however, was strongly convinced of the superiority of America's ideology of Capitalism over the Soviet ideology of Communism and did not adhere to Stalin's requests, but only took a tougher stance towards the Soviet Union, like his administration advised him to do. The Americans believed that the Cold War was a direct consequence of Stalin's behavior towards them. They had merely reacted to Soviet expansion and aggression in a defensive and adequate way. ${ }^{1}$

However, at the end of the Cold War, another interpretation emerged. According to this school, both the USSR and the US should be blamed for the start of the Cold War. However, ideology had not been the root of their actions. Perceptions and concepts about the other held by both superpowers were much more important in shaping foreign policy after the Second World War than reality had been. Perceptions overruled rationality in the decisionmaking processes of the superpowers and created a new reality, which was based on the idea that the other superpower posed a direct danger to their security. ${ }^{2}$

\section{American foreign policy in the Middle East after the Second World War}

From the start of the Cold War, both superpower states tried to convince other countries of the superiority of their own ideology. Together with the fear for the other superpower taking over the world, this resulted in numerous active interventions by both superpowers in world politics from the Second World War onwards. These conflicts were called "wars by proxy" and took place in the so-called "Third World" that was made up of countries outside the US and their allies or the Soviet sphere of influence. This "Third 
World" included Africa, Latin America, and Asia. Nationalism was an important force in these countries' national politics, but the superpowers tried to bend that nationalism to their own interests. According to Stalin, for example, international politics were simply an extension of Soviet politics, and subject to a zero-sum-game with America. This meant that every country lost to America diminished the power of the Soviet Union and vice versa, which made every single country worthy of intervention. ${ }^{3}$

The interventions of both superpowers made the Third World a danger on its own, for these wars by proxy were often not very successful. In the case of Israel, in the period in which the Cold War was just beginning to emerge, it was not beneficial at all or even disastrous for the Soviet Union and the US to take position in the conflict between Jews and Arabs over the land Palestine. Jewish immigrants and the Zionist leaders of the Jewish Agency were pitted against the British, an ally of the Americans, the Palestinian Arabs, and the neighboring Arab countries. The United Nations (UN) partition plan meant to solve the conflict was a proposal to separate Palestine into an Arab and an Israeli state. Resolution 181 of this plan was approved on November 29, 1947 , at the strong dismay of the Arab countries. It was not surprising that, in reaction to the declaration of independence by David Ben-Gurion on May 14, 1948, half a year after the vote for the UN partition plan, a coalition of Arab countries attacked Israel in order to gain land beyond the borders set by the UN partition plan of resolution 181 , and installed a Palestinian government. Only in January 1949, the fighting stopped, when Israel had gained a lot of territory in comparison to the original UN partition plan. ${ }^{4}$

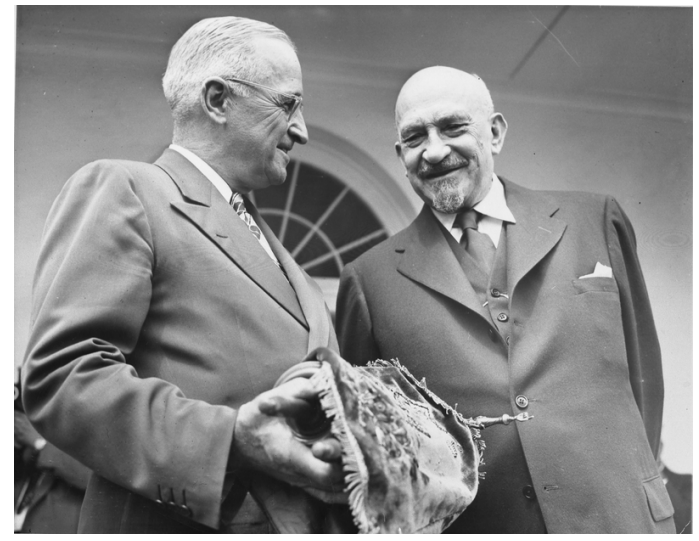

Figure 1: Elinor Borenstine, "President Harry S. Truman and Dr. Chaim Weizmann Meet at the White House", Truman Library Photographs, Edward Jacobson Papers, May 25, 1948, Access September 1, 2019, https://www. trumanlibrary.gov/photograph-records/2008-266. 


\section{Graafland}

\section{An ambivalent position}

Even though there had always been a strong historical and religious connection between the Zionists that established the Israeli state and the Christian Americans, there was a fierce debate in the administration of Truman over the recognition of such a state. Many of Truman's advisors were against the United Nations partition plan, because they thought this was a solution that would destabilize the region and go directly against the interests of the Americans. If the region would fall into conflict, the Arabs could cut the oil access of the West that the West so badly needed after the Second World War. Moreover, a power vacuum would surely be filled by the new rival superpower: the USSR. ${ }^{5}$

The Americans had feared that the representatives of the Soviet Union would not vote in favor of the UN partition plan on November 29, 1947, in order to gain approval of the Arab states. Many administrators under Truman pleaded for an international trusteeship over Palestine instead. To the Americans' surprise, the Soviet representative at the UN, Andrei Andreyevich Gromyko, fully supported the partition plan when the vote came up. When the Zionists proclaimed their own state within half a year of this vote, Truman surpassed his advisors and supported partition.

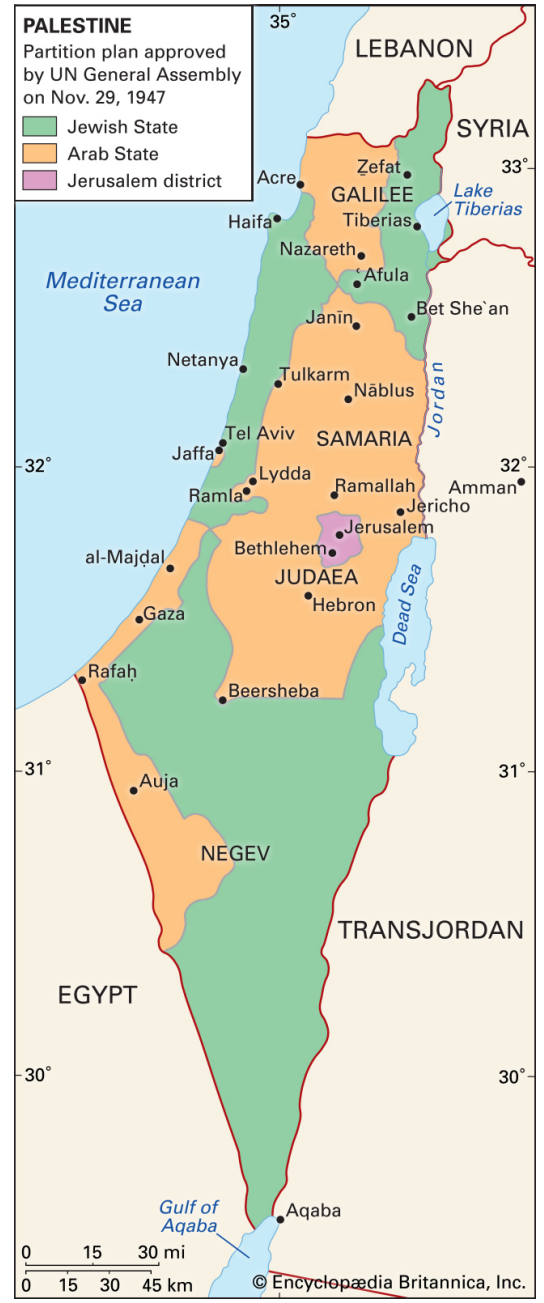

Figure 1: Elinor Borenstine, "President HarryS. Truman and Dr. Chaim Weizmann Meet at the White House", Truman Library Photographs, Edward Jacobson Papers, May 25, 1948, Access September 1, 2019, https://www.trumanlibrary.gov/ photograph-records/2008-266. 
He refused, however, to lift the UN arms embargo that was established in the Middle East afterwards, even though the Zionist leaders repeatedly asked him to do so. ${ }^{6}$

Thus, the position of America towards the Israeli state was by all means ambivalent up to at least two years after Israel's establishment. America's alliance to the Jewish state was never a logical outcome of the historical context either, for it jeopardized good relations with the Arab rivals of Israel. ${ }^{7}$ Thus, when analyzing the primary documents of the American administration on the recognition of the Israeli state between 1947 and 1948, the image of a divided administration arises clearly. Cold War perceptions and suspicions were the main cause of this division.

\section{The "waiting game" in the Middle East}

The Americans perceived five clear threats from the Soviets. First of all, there was the cultural threat which entailed that the Soviets could easily spread enthusiasm for the ideology of Communism in the Middle East, which conflicted with the American ideology of Capitalism. Secondly, the Soviets were keen on getting access to oil resources and establish longlasting economic ties with the states of the Middle East. Thirdly, through Jewish immigration from the Soviet states into Palestine, the Soviets posed a social threat to the Americans in the Middle East. Fourthly, the conflict could offer the Soviets the opportunity to send troops to Palestine in name of the UN, which directly threatened the military presence of America in the region. Also, any Soviet delivery of arms to the Jews would increase the Soviet Union's power in the Middle East. These threats were clear and were discussed frequently in American state documents. ${ }^{8}$ For example, the Central Intelligence Agency (CIA) wrote in a report of July 1948: "Communist agents in the Arab countries will probably exert themselves to stir up the people against their governments in order to bring about the downfall of the present regime". 9

However, in between the lines, all these threats together were described by the Americans as one big threat that the Americans reckoned with in their decisions regarding the recognition of the state of Israel. In the primary documents of the American government on the conflict in Palestine, the Soviet Union is not often the main subject. Still, in many of these documents, the Soviet threat was given important, though not elaborate, consideration in every decision that the Americans made in the Middle East. It seemed 


\section{Graafland}

as if the Soviet threat was always on the American mind.

In January 1947, the Soviets mentioned that they thought the Americans were playing a "Near Eastern game" in which they expanded their economic, military and political power. ${ }^{10}$ The American ambassador in Britain, Lewis Douglas, used this image of a global "game" for the Middle East frequently in his own documents. ${ }^{11}$ In a document repeating the words of the Iraqi representative at the UN, Naji al-Asil, the "game of the Soviet Union" was mentioned as well. ${ }^{12}$ Mahmoud Fawzi Bey of the Egyptian delegation to the UN also "felt sure the Soviet Union would play the game to serve their own interests". ${ }^{13}$ However, it never becomes clear what was meant by this "Soviet game". The term was vague and threatening and pointed to a general geostrategic threat.

Multiple authors and institutions of the American government interpreted this geostrategic threat of the Soviets in the Middle East differently. First of all, institutions that were very worried about the Soviet presence in the Middle East were the CIA, the Policy Planning Staff (PPS), the National Security Council and the Department of Defense. The main fears expressed in security reports of these institutions can be summarized as follows: the Soviet Union would replace Britain and the US as the dominant power in the Middle East. Because of America's favorable position vis-á-vis the Jews, the Arabs would turn to the Russians. For the Russians, Palestine was the door to the Middle East and if they gained a foothold there, the region would become unstable. In such a restive situation, the Soviets would certainly try to buy the Arab peoples' loyalty and alienate them from the West. ${ }^{14}$ This would give the Soviets access to oil and friends in the Middle East and in the UN that were not too happy with the decisions of the Soviets' rival superpower: the US. Both developments would weaken the geopolitical position of the US in the Middle East.

George Kennan of the PPS feared that cooperation on establishing peace in the Middle East in the UN would only result in the introduction of Soviet troops into Palestine or cooperation between the Soviets and the Arabs in the UN. ${ }^{15}$ In a memorandum of May 1948, he wrote that American national interests should be more important than international cooperation, for the policy of America could only be firm if domestic interests were put first, otherwise America would "undermine the entire policy toward the Soviet Union". ${ }^{16}$ All the Soviet Union had to do was to remain passive for a while if it wanted to achieve its goals in Palestine. ${ }^{17}$ The Secretary of Defense, James 
Forrestal, added that the American policy in the Middle East impacted the whole "world military position" of the US. ${ }^{18}$ The Soviets would be able to occupy the Middle East with only a small force and cut off the Americans from the oil resources that were key to the success of the European Recovery Program that was meant to recover the Western European economy and stabilize Germany. ${ }^{19}$ Cooperation in the UN was therefore no option.

The idea that the Soviet Union did not have to make an effort to gain the friendship of the Arabs, was already coined as the "waiting game" in 1947 by the chargé in the Soviet Union, Andrew Durbrow. ${ }^{20}$ In early 1947, the Americans were still unsure which side the Soviet Union would pick in Palestine, so the telegrams of the ambassadors in Eastern Europe were valuable sources. Durbrow informed the Secretary of State, George Marshall, in May 1947 that he thought the Soviets would not support a Jewish state, only a Palestinian Arab state. Still, the Soviets would first wait and see, and only later, when it could not be avoided any longer, pick the Arab side. He was partly mistaken, for the Russians did recognize the Jewish state on the very same day that the Jewish Agency asked them to and kept supporting the Jewish state in the following year. At the end of 1948, however, it was clear that the Soviets had finally chosen the Arab side in the conflict after all, once it appeared that they would not gain further favor or influence in the Jewish state. ${ }^{21}$

To verify the claims made on the threat of Russian expansion in the Middle East, the Americans were informed by their personnel at the Office of Near Eastern Affairs (NEA), who stood in close contact with Arab officials. These documents point out that the Arabs perceived the partition plan as a means of Russia to open the door to their region. The Arabs were certainly not much in favor of the Russians in 1947, for the Russians increased the instability that the acceptance of the partition plan by the UN had caused. At the same time, the Arabs knew they could make good use of the Cold War rivalry. The Arabs had been approached by the Soviets in October 1947 , before the partition plan was voted for, to make a deal..$^{22}$ Although any Arab-Soviet cooperation would not be "a permanent orientation", its danger was stressed nonetheless and could not be overestimated. ${ }^{23}$ According to Warren Austin, the American representative at the UN, the Russians would certainly try to "take advantage of the political changes for which they are hoping in the Arab states" ${ }^{24}$

Many concerns of the NEA were repeated by the State Department and the British. The State Department members, Marshall in particular, 


\section{Graafland}

did not want to extend de jure recognition to the Provisional Government of Israel. Recognition would put the US in a difficult position if the Soviets befriended the Provisional Government's members and tried to influence Israeli policy. ${ }^{25}$ Although a good solution to the situation in Palestine was necessary, "strategic, economic, and political interests of the United States in the Near East" had priority. ${ }^{26}$ This meant that the status quo had to be maintained and the global situation kept in mind. ${ }^{27}$ In a memorandum of September 1948, Marshall made his position very clear: "the expansionist tendencies of the U.S.S.R. in this area [Palestine] further complicated the already complex situation". ${ }^{28}$ The continuously changing position of America on the Middle East and relations with the state of Israel would only make it hard "to counter aggressive Communist moves" ${ }^{29}$

The British blocked mutual efforts of the UN to reconcile the Jews and the Arabs, because they were afraid that any support in favor of the Jews would directly diminish their own influence in the region. Douglas sent numerous telegrams informing the Department of State of the gravity of the situation and the danger of Soviet expansion into the Middle East. ${ }^{30}$ The British Embassy continuously pressed the US to take action against the Soviets, and in line with this, not to support the Jews.

Finally, there were President Truman and his political advisor Clark Clifford, who were both very occupied with the Palestinian question. ${ }^{31}$ Clifford concluded that the American vote for the partition plan was "a moral obligation", which was how Truman perceived it as well. ${ }^{32}$ All the Americans had to do was get out of their state of indecision, reconfirm their support for the partition plan, and recognize the Jewish state. Every other solution would only lead to more violence and turmoil, and delay peace. Truman did not want the USSR to gain by American policy mistakes in the Middle East. At the same time, he often made clear that he was on the side of the Jews and disagreed with Marshall on the matter of recognition. The President got his way in continuing Jewish immigration to Palestine and the immediate recognition of the state of Israel, but he did not want to lift the UN arms embargo, which angered both the Jews and the Arabs. ${ }^{33}$ Overall, Truman did not lead his administration and was torn between his own ideas and his administration's wishes. 


\section{Conclusion}

The case of the Americans' strategy concerning the recognition of the state of Israel, shows that self-created and constructed perceptions, rather than fixed ideological ideas determined the American foreign policy at the start of the Cold War. Therefore, the alliance between the US and Israel was not as strong as currently thought in the first years of Israel's establishment. The Americans were continuously occupied with the geostrategic threat that the Soviets could pose to their national interests and security in the Middle East. This threat of the Soviet Union in the Middle East was described in general and vague terms, which lacked a clear focus in how the Soviets directly threatened America's position in the Middle East. As a consequence, the Americans failed to steer their own course, and merely reacted to historical developments and events. This unclear policy delayed peace in Palestine and distanced the Israeli state from the Americans. In this way, the division in Truman's administration as a result of the Cold War actively increased the Soviet foothold in the Middle East. The Americans were playing the "waiting game" of the Russians for too long.

\section{Notes}

1. John Lewis Gaddis, We Now Know: Rethinking Cold War History (Oxford: Oxford University Press, 1997), 8, 13-15 and 20; Michael F. Hopkins, "Historiographical Reviews: Continuing Debate and New Approaches in Cold War History," The Historical Journal 50 (2007), 914-916; Melvyn P. Leffler, "The Cold War: What Do "We Now Know"?," American Historical Review 104 (1999), 503-504.

2. Hopkins, "Historiographical Reviews," 916; Leffler, "The Cold War," 508-512 and 517; Odd Arne Westad, "The Cold War and the international history of the twentieth century," in The Cambridge History of the Cold War, vol. 1: Origins, ed. Melvyn P. Leffler and Odd Arne Westad (Cambridge: Cambridge University Press, 2010), 6-7.

3. George C. Herring, "From Colony to Superpower: U.S. Foreign Relations since 1776," Oxford History of the United States (Oxford: Oxford University Press, 2008), 596; Richard H. Immerman and Petra Goedde, "Introduction," in The Oxford Handbook of the Cold War (Oxford Handbooks Online, 2013), 7; Eugene L. Rogan and Avi Shlaim, "Introduction," in The War for Palestine: Rewriting the History of 1948 (Cambridge: Cambridge University Press, 2001), 1 and 5; Federico Romero, "Cold War historiography at the crossroads," Cold War History 14 (2014), 693 and 698; Odd Arne Westad, The Global Cold War: Third World Interventions and the Making of Our Times (Cambridge: Cambridge University Press, 2007), 3-4, 99 and 101. 


\section{Graafland}

4. Gyoo-Hyoung Kahng, "Zionism, Israel, and the Soviet Union: A Study in the Rise and Fall of Brief Soviet-Israeli Friendship from 1945 to 1955," Global Economic Review 27 (1998), 96-97; Avi Shlaim, "Israel and the Arab coalition in 1948," in The war for Palestine: Rewriting the History of 1948, eds. Eugene L. Rogan and Avi Shlaim (Cambridge: Cambridge University Press, 2001), 81, 84 and 100; The author couldn't find the number of percentages that was assigned to the Jews and Arabs in the UN partition plan, but in figure 2, a map is included that shows the borders of the Jewish state and the Arab state in Palestine according to the partition plan as voted for in the UN on November 29, 1947 in resolution 181.

5. Irene L. Gendzier, Dying to Forget: Oil, Power, Palestine, and the Foundations of U.S. Policy in the Middle East (New York: Columbia University Press, 2015), 94 and 111; Harold F. Gosnell, Truman's Crises: A Political Biography of Harry S. Truman (Connecticut: Greenwood Press, 1980), 360-361; Douglas Little, American Orientalism: The United States and the Middle East since 1945 (London: I.B. Tauris \& Co. Ltd., 2002), 4-5; David S. Painter, "Oil, resources, and the Cold War, 1945-1962," in The Cambridge History of the Cold War, Vol. 1, Origins, eds. Melvyn P. Leffler and Odd Arne Westad (Cambridge: Cambridge University Press, 2010), 496-497.

6. Bruce J. Evensen, "The Limits of Presidential Leadership: Truman at War with Zionists, the Press, Public Opinion and His Own State Department Over Palestine," Presidential Studies Quarterly 23 (1993), 269-270; Gosnell, Truman's Crises, 362363.

7. Little, American Orientalism, 78; Mart, "Tough Guys and American Cold War Policy," 361; Dennis Merrill, 'Introduction', in Documentary History of the Truman Presidency, vol. 24: The United States' Recognition of Israel (University Publications of America, 1998), xxxii.

8. These reasons are discussed more elaborately in the thesis on which this article was based, freely accessible via https://www.academia.edu/40225443/The_Soviet_game_ in_the_Middle_East_American_Cold_War_Perceptions_and_the_Support_for_ the_State_of_Israel.

9. Central Intelligence Agency, "Document 471," in Foreign Relations of the United States, 1948, vol. 5, pt 2: The Near East, South Asia, and Africa, eds. Herbert A. Fine and Paul Claussen (United States Government Printing Office Washington, 1976 (ebook)), hereafter shortened to FRUS, 1948, pt 2.

10. Walter Smith, “Document 439," in Foreign Relations of the United States, 1947, vol. 5: The Near East and Africa, gen. ed. S. Everett Gleason (United States Government Printing Office Washington, 1971 (ebook)), hereafter shortened to FRUS, 1947.

11. Lewis Douglas, "Document 686," in FRUS, 1948, pt 2; Lewis Douglas, "Document 700." in FRUS, 1948, pt 2; George Marshall, “Document 861," in FRUS, 1947.

12. Warren Austin, "Document 318," in FRUS, 1948, pt 2.

13. Henry Villard, "Document 603," in FRUS, 1948, pt 2.

14. Central Intelligence Agency, "Document 67," in FRUS, 1948, pt 2; Central Intelligence Agency, "Document 471;" Central Intelligence Agency, "Report: The Consequences of the Partition of Palestine, November 28, 1947," CIA research reports: Middle East, 1946-1976, Reel 3:0043, ed. Paul Kesaris, Microfilm Project of University 
Publications of America (University Publications of America, 1983), access via Roosevelt Institute of American Studies, Middelburg on March 19, 2018; George Kennan, "Document 10," in FRUS, 1948, pt 2; Andrew McFarland, "Document 14," in Documentary History of the Truman Presidency, gen. ed. Dennis Merrill, vol. 24: The United States' Recognition of Israel (University Publications of America, 1998); National Security Council, "Document 44," in FRUS, 1948, pt 2.

15. Central Intelligence Agency, "Report: Possible Developments in Palestine, February 28, 1948," CIA research reports: Middle East, 1946-1976, Reel 3:0043, ed. Paul Kesaris, Microfilm Project of University Publications of America (University Publications of America, 1983). Access via Roosevelt Institute of American Studies, Middelburg on March 19, 2018; George Kennan, "Document 58," in FRUS, 1948, pt 2; Thomas Power Jr., "Document 794," in FRUS, 1947; Gordon Knox, "Document 843," in FRUS, 1947; Warren Austin, "Document 227," in FRUS, 1948, pt 2; Warren Austin, "Document 292," in FRUS, 1948, pt 2.

16. George Kennan, "Document 288," in FRUS, 1948, pt 2.

17. Central Intelligence Agency, "Document 471."

18. James Forrestal, "Document 526," in FRUS, 1948, pt 2.

19. Ibid.

20. Elbridge Durbrow, “Document 758," in FRUS, 1947.

21. Elbridge Durbrow, "Document 278," in FRUS, 1948, pt 2; Durbrow, "Document 758”; James Penfield, "Document 797," in FRUS, 1948, pt 2; Walter Smith, "Document 335," in FRUS, 1948, pt 2; Walter Smith, "Document 724," in FRUS, 1947.

22. Knox, "Document 843;" Samuel Kopper, "Document 804," in FRUS, 1947; Robert Macatee, "Document 31," in FRUS, 1948, pt 2; James McDonald, "Document 717," in FRUS, 1948, pt 2; Robert Memminger, “Document 884," in FRUS, 1947; Thomas Wasson, "Document 295," in FRUS, 1948, pt 2.

23. Loy Henderson, "Document 179," in FRUS, 1948, pt 2; Kopper, "Document 804"; Joseph Satterthwaite, "Document 450," in FRUS, 1948, pt 2.

24. Austin, "Document 292."

25. Department of State, "Document 552," in FRUS, 1948, pt 2; Loy Henderson, "Document 796," in FRUS, 1947; Robert Lovett, "Document 461," in FRUS, 1948, pt 2; George Marshall, "Document 246," in FRUS, 1948, pt 2.

26. Department of State, "Document 765," in FRUS, 1947; Department of State, "Document 802," in FRUS, 1947.

27. Robert Lovett, "Document 134," in FRUS, 1948, pt 2; George Marshall, "Document 893," in FRUS, 1947.

28. George Marshall, "Document 568," in FRUS, 1948, pt 2.

29. Robert Lovett, "Document 701," in FRUS, 1948, pt 2.

30. British Embassy in America, "Document 1," in FRUS, 1948, pt 2; British Embassy in America, "Document 300," in FRUS, 1948, pt 2; Lewis Douglas, "Document 313," in FRUS, 1948, pt 2; Douglas, "Document 686." The first telegram of Douglas was sent on December 17, 1947: Frank Roberts, "Document 904," in FRUS, 1947. After that, many followed in 1948.

31. Dean Acheson, "Document 753," in FRUS, 1947; Marshall, "Document 246;" 
McCullough, Truman, 595-596.

32. Clark Clifford, "Document 23," in Documentary History of the Truman Presidency, gen. ed. Dennis Merrill, vol. 24: The United States' Recognition of Israel (University Publications of America, 1998); Clark Clifford, "Document 577," in FRUS, 1948, pt 2; Little, American Orientalism, 87 and 121.

33. "Document 1," in Foreign Relations of the United States, 1948, vol. 5, pt 1, eds. Herbert A. Fine and David H. Stauffer (United States Government Printing Office Washington, 1975 (ebook)); Acheson, "Document 753;" Clark Clifford, "Document 39," in Documentary History of the Truman Presidency, gen. ed. Dennis Merrill, vol. 24: The United States' Recognition of Israel (University Publications of America, 1998)); Clifford, "Document 577;" Hahn, 'Into the Middle of a Fight', 32; Little, American Orientalism, 84-87; Marshall, "Document 246;" Harry Truman, "Document 44," in Documentary History of the Truman Presidency, gen. ed. Dennis Merrill, vol. 24: The United States' Recognition of Israel (University Publications of America, 1998). 